\title{
Pengaruh Pendapatan Asli Daerah (PAD), Dana Alokasi Umum (DAU), Dana Alokasi Khusus (DAK) Terhadap Belanja Modal
}

The Influence of Local Revenue (PAD), General Allocation Fund (DAU), Special Allocation Fund

(DAK) on Capital Expenditure

\author{
Suryana \\ Fakultas Ekonomi dan Bisnis Universitas Widyatama (Utama), Bandung, Indonesia \\ suryana.se@widyatama.ac.id
}

\begin{abstract}
This study is meant to examine the influence of local own resource revenue (PAD), General Allocation Fund (DAU) and Special Allocation Fund (DAK) to the Capital Expenditure of cities government in West Java, research background caused in the first semester of 2013 West Java provincial government has not maximized the allocation of capital expenditure and the Ministry of Home Affairs stated that the absorption of capital expenditure realization, only reached 11.4\%. The method used is Eksplanatory Research. 9 Cities in the West Java government area are the population used in this study, the period from 2012 to 2015. Non-probality sampling is a technique in determining samples, where the saturated sampling method was used in this study. The results of calculations with multiple linear regression show that partially that regional original income (PAD), general allocation funds (DAU), and special allocation funds (DAK) affect the allocation of capital expenditure by $87.0 \%$.
\end{abstract}

\begin{abstract}
Abstrak
Penelitian ini bertujuan menguji Pengaruh Pendapatan Asli Daerah (PAD), Dana Alokasi Umum (DAU) dan Dana Alokasi Khusus (DAK) terhadap Belanja Daerah pada pemerintah Daerah kota di Jawa Barat, latarbelakang penelitian disebabkan pada semester I tahun 2013 pemerintah provinsi Jawa Barat belum memaksimalkan pengalokasian belanja modal dan Kementerian Dalam Negeri menyatakan bahwa daya serap realisasi belanja modal, baru mencapai $11,4 \%$. Metode yang digunakan adalah Eksplanatory Research. 9 Kota yang berada di wilayah pemerintahan Jawa Barat merupakan populasi yang digunakan pada penelitian ini, dengan periode waktu tahun 2012 sampai dengan 2015. Sementara Non-probality sampling merupakan teknik dalam penentuan sample dimana metode sampling jenuh yang dipakai dalam penelitian ini. Hasil perhitungan dengan regresi linear berganda menunjukan bahwa secara parsial bahwa pendapatan asli daerah(PAD), dana alokasi umum(DAU), dan dana alokasi khusus(DAK) berpengaruh terhadap alokasi belanja modal sebesar $87,0 \%$.
\end{abstract}

Kata Kunci: pendapatan asli daerah; dana alokasi umum; belanja modal.

\section{PENDAHULUAN}

Negara Indonesia memberlakukan sistem otonomi daerah demi terwujudnya keadilan dan kemakmuran rakyat Indonesia tanpa meninggalkan prinsip Negara kesatuan Republik Indonesia, maksud dari otonomi daerah yaitu pemerintah daerah dapat secara mandiri dalam membuat kebijakan-kebijakan terkait dalam urusan pemerintahannya demi kepentingan masyarakat sesuai perundang-undangan yang berlaku pada pemerintahan Republik Indonesia, namun dalam pemberlakukan otonomi daerah ini menimbulkan permasalahan-permasalahan yang baru, seperti : kewenangan yang tumpang tindih, pelayanan publik, politik identitas diri, orientasi kekuasaan, lembaga perwakilan, pemekaran daerah, pemilihan kepala daerah langsung dan Anggaran. Salah satu permasalahan dalam pelaksanaan otonomi daerah yaitu tentang anggaran yang dimiliki oleh suatu pemerintah daerah, tidak sedikit pemerintah daerah tidak memiliki anggaran yang cukup dalam mengurus dan mengatur urusan pemerintahan.

Oleh karena itu untuk mengatasi permasalahan tersebut yang terjadi disuatu daerah, pemerintah pusat perlu menata keuangan baik untuk pemerintah daerah pemerintah pusat maupun untuk pemerintah 
pusat, sebagaimana tertulis dalam undang-undang nomer 3 tahun 2004: bahwa pendapatan asli daerah(PAD) adalah pendapatan yang dipungut sesuai dengan kebijakan daerah masing-masing, Dana Alokasi Umum(DAU) adalah dana diperoleh dari Anggaran Pendapatan Belanja dan Negera (APBN), dana ini bertujuan untuk pemerataan kemampuan keuangan antar pemerintah-daerah untuk membiayai kebutuhan dimasing-masing pemerintah daerah.

Pengeluaran anggaran yang dipakai dalam memperolehan aset tidak lancar dan aset lainnya dan berdampak pada pemerintah daerah sehingga akan memberikan manfaat lebih dari satu periode disebut dengan Belanja Modal. Belanja Modal ini berkaitan erat dengan rencana penggunaan keuangan dalam jangka panjang, seperti untuk pemeliharaan aset tetap tersebut. Untuk mengimplementasikan pembiayaan penyelenggaraan pemerintahan dan memberi pelayanan kepada masyarakat. pemerintahan daerah dapat melakukan pungutan kepada masyarakat terkait dengan pajak daerah atau retribusi dan dipersilahkan untuk mengelola Sumber Daya Alam secara mandiri. Jenis Sumber dana pada pemerintah daerah diantaranya adalah sebagai berikut: Pendapatan Asli Daerah (PAD), Dana Perimbangan DAU dan DAK dan Pinjaman Daerah, Dekonsentrasi dan Tugas Pembantuan.

Anggaran Pendapatan dan Belanja Daerah (APBD) wajib di alokasikan sebagai wujud dalam meningkatkan pelayanan publik. Dalam (Wijanarko, 2013) Pemerintah provinsi Jawa Barat masih belum memaksimalkan belanja modal di semester satu pada tahun 2013 pengalokasian belanja modal masih lebih rendah dibanding pada tahun 2012. Dikutip dari Dirjen Bina Keuangan Daerah Kementerian Dalam Negeri pada 8 September 2015 menyatakan bahwa daya serap realisasi belanja modal baru mencapai $11,4 \%$ pada APBD provinsi di tahun 2015, dan baru mencapai $13,8 \%$ daya serap realisasi belanja modal pada kabupaten/kota, Pemerintah Daerah Kalimantan Utara 19\%, Pemerintah DKI Jakarta 19\%, Pemerintah Daerah Papua $22 \%$ masih rendah dalam penyerapan anggarannya, dan Jawa Barat $26 \%$ dibanding dengan provinsi lainnya sudah mencapai diatas $50 \%$, seperti Kalimantan Tengah, Gorontalo, Maluku Utara dan Sulawesi Tenggara (Faisal, 2015).

Berdasarkan paparan diatas, maka penelitian ini bertujuan untuk menguji : Apakah Pendapatan Asli Daerah (PAD) berpengaruh signifikan terhadap Belanja Modal dan Apakah Dana Alokasi Umum (DAU) berpengaruh signifikan terhadap belanja modal?

\section{KERANGKA PENELITIAN \& HIPOTESIS}

\section{Otonomi Daerah}

Pengertian Otonomi daerah menurut UU Nomor 23 tahun 2014 (sebagai pengganti UndangUndang Nomor 32 tahun 2004 tentang Pemerintahan Daerah) menyebutkan bahwa :

Otonomi Daerah yaitu merupakan hak daerah otonom, wewenang daerah otonom, serta kewajiban daerah otonom dalam hal membuat kebijakan-kebijakan mengenai urusan pemerintahan dan kepentingan masyarakat setempat dalam sistem NKRI dapat dilakukan secara mandiri.

Dalam (Adisasmita, 2011:3) bahwa Otonomi daerah baik kota maupun Kabupaten dapat menjalankan secara luas, bertanggung jawab terhadap pemerintah daerah secara proporsional yang berkeadilan serta dapat memanfaatkan sumber daya secara maksimal.

\section{Anggaran Pendapatan dan Belanja Daerah (APBD)}

Berdasarkan UU No. 17/2003 mengenai Keuangan Negara bahwa Anggaran Pendapatan dan Belanja Daerah (APBD) yaitu rencana keuangan tahunan pemerintah daerah yang disetujui oleh DPRD. Sementara menurut UU No. 33/2004 bahwa (APBD) yaitu sebagai berikut:

(APBD) yaitu peraturan daerah yang membahas terkait dengan rencana keuangan tahunan Pemerintahan Daerah, APBD ini disetujui dan ditetapkan oleh DPRD bersama Pemerintah Daerah. Berdasarkan ketentuan dalam Undang-Undang Nomor 17 tahun 2003 tentang Keuangan Negara menyebutkan bahwa fungsi anggaran pendapatan dan belanja daerah yaitu : (1) sebagai dasar buat melaksanakan pendapatan dan belanja pada periode berjalan, dimana disebut dengan Fungsi Otorisasi. (2) sebagai pedoman untuk manajemen dalam merencanakan kegiatan pada tahun yang berjalan atau disebut juga dengan fungsi Perencanaan. (3) sebagai pedoman dalam menilai kesesuaian penyelenggaraan pemerintah daerah dengan ketentuan yang berlaku, dimana hal ini disebut Fungsi Pengawasan. (4) sebagai monitoring untuk mengurangi pengangguran dan efisiensi dan efektivitas sumber daya, dapat juga disebut sebagai Fungsi Alokasi. (5) untuk mengukur rasa keadilan dan kepatutan, hal ini disebut juga sebagai Fungsi Distribusi (6) menjadi alat keseimbangan dalam mengupayakan stabilitas perekonomian, atau juga dapat disebut sebagai fungsi Stabilisasi. 


\section{Pendapatan Asli Daerah (PAD)}

Pengertian PAD Menurut UU. No.33/2004 yaitu: Pendapatan asli daerah(PAD) yaitu pendapatan daerah yang didapat pemerintah daerah yang dipungut berdasarkan peraturan daerah sesuai dengan peraturan perundang-undangan.

Dalam Darise (2007:43) menyebutkan pendapatan asli daerah(PAD) yaitu sebagai berikut : Pendapatan asli daerah (PAD) yaitu pendapatan yang diperoleh pemerintah daerah yang dipungut berdasarkan peraturan daerah sesuai dengan peraturan perundang-undangan."

Menurut Halim dan Kusufi (2012:101) menyebutkan bahwa pendapatan asli daerah adalah sebagai berikut : seluruh penerimaan pemerintahan daerah bersumber dari hasil perekonomian asli didaerah tersebut.

menurut pengertian-pengertian di atas bahwa PAD adalah segala pemasukan yang diterima oleh pemerintah daerah bersumber dari seluruh hasil perekonomian asli di daerah tersebut. UU No. 33/ 2004 mengenai Perimbangan Keuangan. Menyatakan bahwa sebagai wujud desentralisasi, bahwa pemerintah daerah harus melaksanakan pendanaan atas berjalannya kegiatan mandiri dapat dilakukan secara mandiri.

\section{Dana Perimbangan}

Berdasrkan UU. No. 332004 tentang Perimbangan Keuangan antara pemerintah pusat dan daerah menyebutkan bahwa pengertian dana perimbangan adalah sebagai berikut :

Dana perimbangan yaitu dana yang berasal dari anggaran Pendapatan Belanja Negara yang dikhususkan untuk kegiatan pemerintah daerah sebagai wujud dari implementasi desentralisasi.

Menurut Widjaja (2009:129) menyebutkan bahwa pengertian dana perimbangan adalah dana yang berasal dari pemerintah pusat dengan wujud anggaran pendapatan dan belanja negara atau disebut APBN, dalam rangka mewujudkan Kerangka Pemikiran desentralisasi demi peningkatan kesejahteraan dan wujud meningkatkan kesejahteraan masyarakat ke arah lebih baik.

\section{Dana Alokasi Umum}

UU. No. 33/2004 tentang Perimbangan Keuangan antara Pemerintah Pusat dan Daerah menyebutkan bahwa pengertian dana alokasi umum(DAU) adalah dana berasal dari penghasilan Anggarann Pendapatan dan Belanja Negara yang dikhususkan sebagai pemerataan kemampuan keuangan diantara pemerintah daerah yang satu dengan pemerintah daerah yang lainnya, serta mewujudkan implementasi atas kebijakan desentralisasi.

Sementara dalam karya Darise (2007:84) menyebutkan pengertiannya yaitu Dana bersumber dari Anggaran Pendapatan dan Belanja Negara atas implementasi kebijakan pemerintah pusat terkait dengan desentralisasi yang bertujuan untuk pemerataan kemampuan keuangan diantara daerah satu dengan daerah yang lainnya

\section{Belanja Modal}

Merujuk Perpu No.71 Tahun 2010 tentang Standar Akuntansi Pemerintahan menyebutkan bahwa definisi belanja modal yaitu pengeluaran anggaran dengan tujuan mendapatkan aset tetap dan aset lainnya untuk dapat digunakan dalam menjalankan roda pemerintahan yang lebih dari satu periode akuntansi, seperti mendapatakan aset tanah, gedung dan bangunan, peralatan, aset tak berwujud."

Menurut Mardiasmo (2009:67) menyebutkan bahwa pengertian belanja modal yaitu penggunaan dana anggaran untuk mendapatkan aset yang memiliki manfaatnya lebih dari satu tahun anggaran dan menambah harta pemerintah yang pada akhirnya akan menambah biaya pemeliharaan.

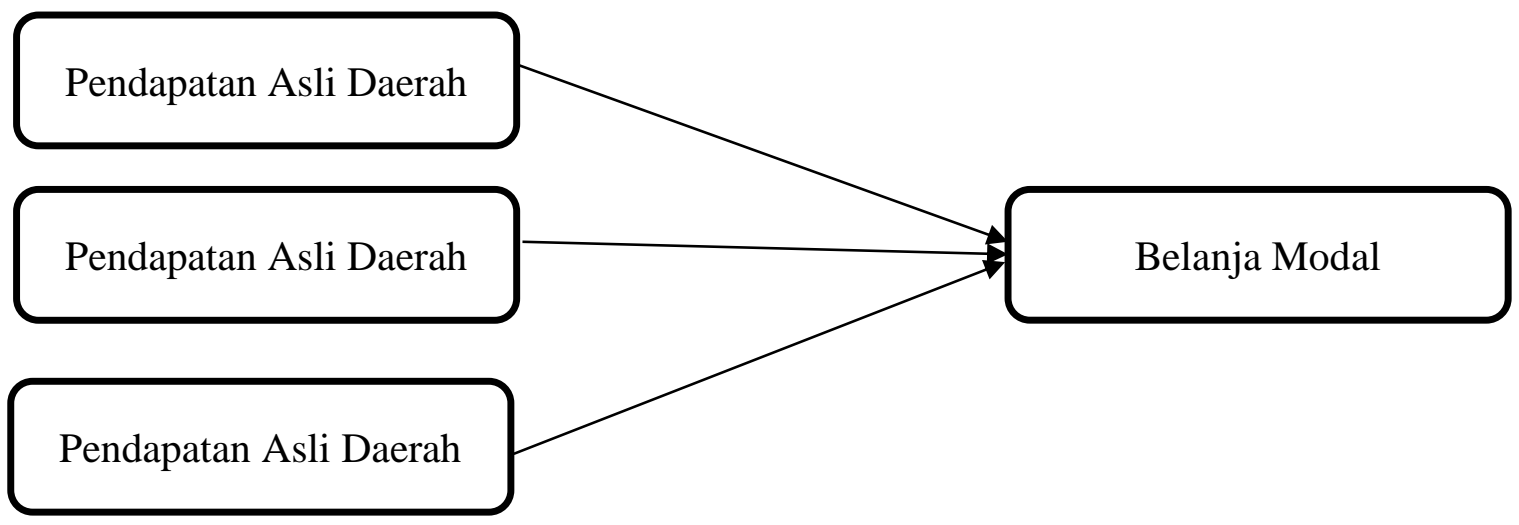

Gambar 1. Kerangka Konseptual Penilitian 
$\mathrm{H}_{1}$ : Pendapatan Asli Daerah berpengaruh positif terhadap Belanja Modal.

$\mathrm{H}_{2}$ : Dana Alokasi Umum berpengaruh positif terhadap Belanja Modal.

$\mathrm{H}_{3}$ : Dana Alokasi Khusus berpengaruh positif terhadap Belanja Modal.

\section{METODE PENELITIAN}

Objek penelitian yang akan diteliti dalam hal ini adalah Pendapatan Asli Daerah (PAD), Dana Alokasi Umum (DAU), dan Dana Alokasi Khusus (DAK).

\section{Populasi dan Sampel Penelitian}

semua populasi dijadikan sample dalam karya tulis ini, yaitu sebanyak 9 kota yang berada diwilayah pemerintah daerah Jawa Barat dengan mulai tahun 2012 sampai dengan tahun 2015.

\section{Jenis Data}

Jenis data didapat dari sumber yang telah dicatat oleh pihak lain, dengan kata lain data sekunder.

Tabel 1. Operasionalisasi Variabel Penelitian

\begin{tabular}{|c|c|c|c|c|}
\hline Variabel & Definisi & Indikator & Pengukuran & Skala \\
\hline $\begin{array}{c}\text { Pendapatan } \\
\text { Asli Daerah } \\
\left(\mathrm{X}_{1}\right)\end{array}$ & $\begin{array}{l}\text { Penghasilan yang diterima } \\
\text { murni dari daerah sesuai } \\
\text { perda (peraturan daerah) } \\
\text { yang berlaku dan sesuai } \\
\text { peraturan perundang- } \\
\text { undangan. } \\
\text { (UU No. } 33 \text { Tahun 2004) }\end{array}$ & $\begin{array}{l}\text { 1. Hasil pengelolaan } \\
\text { kekayaan daerah yang } \\
\text { dipisahkan } \\
\text { 2. Pajak Daerah } \\
\text { 3. Retribusi Daerah } \\
\text { 4. Lain-lain PAD yang sah } \\
\text { (UU No.28 tahun 2009) }\end{array}$ & $\begin{array}{l}\text { Rasio Pertumbuhan PAD } \\
\begin{array}{r}\text { PADt }- \text { PADt-1 x 100\% } \\
=\frac{\text { PADt-1 }}{\text { (Halim, 2007:128) }}\end{array}\end{array}$ & Rasio \\
\hline $\begin{array}{c}\text { Dana Alokasi } \\
\text { Umum (X2) }\end{array}$ & 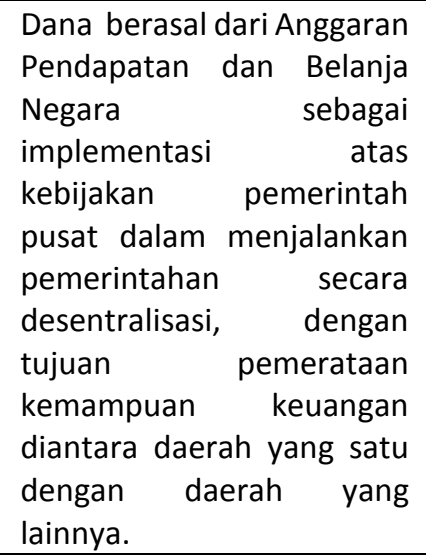 & $\begin{array}{l}\text { Pendapatan APBN } \\
\text { (UU No. } 33 \text { Tahun } \\
2004)\end{array}$ & $\begin{array}{l}\text { Rasio Pertumbuhan DAU } \\
\frac{\text { DAUt }-\mathrm{DAU} \text { t-1 } \times 100 \%}{=} \text { DAUt-1 } \\
\text { (Halim, 2007:128) }\end{array}$ & Rasio \\
\hline $\begin{array}{c}\text { Dana Alokasi } \\
\text { Khusus }\left(X_{3}\right)\end{array}$ & $\begin{array}{l}\text { Dana berasal dari Anggaran } \\
\text { Pendapatan dan Belanja } \\
\text { Negara yang dikhususkan } \\
\text { untuk daerah-daerah } \\
\text { tertentu dalam rangka } \\
\text { membantu pelaksanaan } \\
\text { kegiatan yang dilakukan } \\
\text { oleh pemerintah daerah. }\end{array}$ & $\begin{array}{l}\text { Pendapatan APBN } \\
\text { (UU No. } 33 \text { Thn 2004) }\end{array}$ & $\begin{array}{l}\text { Rasio Pertumbuhan DAK } \\
\frac{\text { DAKt }_{\mathrm{t}}-\mathrm{DAK} \mathrm{t}-1 \times 100 \%}{=} \\
\text { DAK }_{\mathrm{t}-1}\end{array}$ & Rasio \\
\hline
\end{tabular}

\section{HASIL DAN PEMBAHASAN}

\section{Uji Normalitas}

yaitu untuk melihat hasil uji apakah model regresi, variabel pengganggu memiliki distribusi normal atau tidak. Dalam kesempatan ini digunakan uji Jarque Bera menguji normalitas model regresi dan berdasarkan hasil pengolahan data 


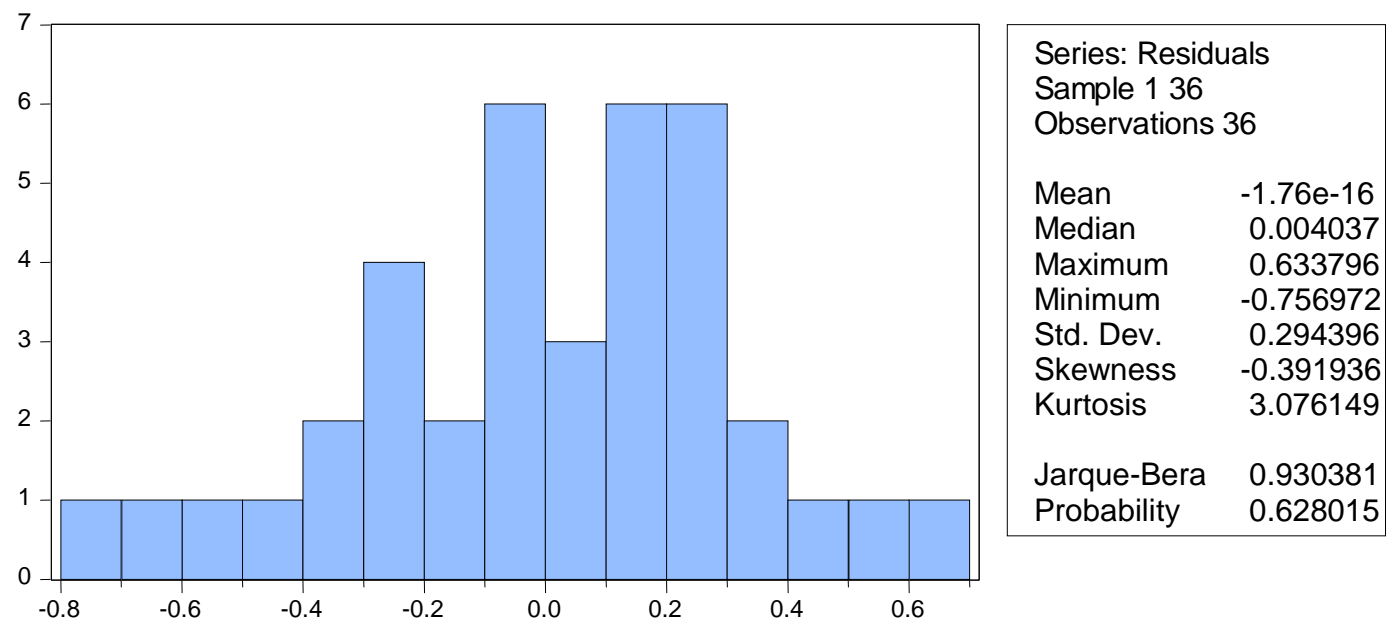

Gambar 2. Uji Normalitas

Berdasarkan data tersebut nilai probalitasnya uji Jarque-Bera sebesar 0,628. Artinya lebih besar dari nilai kekeliriuan 0,05 , jadi dapat diartikan model ini berdisitribusi normal, sehingga sebaran data residual dapat memiliki bentuk kurva distribusi normal.

\section{Uji Multikolinearitas}

uji multikolinieritas untuk melihat apakah data yang digunaka ini terdapat korelasi antar variabel bebas, data yang baik adalah yang tidak memiliki korelasi di antara variabel independen, Imam Ghozali (2013:105). Uji multikolinearitas dalam penelitian ini dilihat dari besarnya nilai tolerance dan lawannya (2) Variance Inflation Factor (VIF). Besarnya nilai Tolerance $\leq 0,10$ atau sama dengan nilai VIF $\geq 10$ "

\section{Tabel 2. Uji Multikolinearitas}

Variance Inflation Factors

Date: 09/08/17 Time: 11:42

Sample: 136

Included observations: 36

\begin{tabular}{cccc}
\hline Variable & $\begin{array}{c}\text { Coefficient } \\
\text { Variance }\end{array}$ & $\begin{array}{c}\text { Uncentered } \\
\text { VIF }\end{array}$ & $\begin{array}{c}\text { Centered } \\
\text { VIF }\end{array}$ \\
PAD & 0.089396 & 3.932641 & 1.687865 \\
DAU & 0.556500 & 4.453332 & 1.683931 \\
DAK & 0.000693 & 1.375711 & 1.263017 \\
C & 0.007870 & 2.988653 & NA \\
\hline
\end{tabular}

Berdasarkan hasil uji multikolineritas di atas dapat diketahui bahwa nilai centered variance inflation factors (VIF) menunjukan nilai masing-masing variabel tidak lebih dari 10 atau $<10$. Kesimpulannya tidak ada multikolinieritas antara variabel bebas.

\section{“Uji Heteroskedastisitas}

Kegunaan dari pengujian ini yaitu untuk melihat apakah model terdapat ketidaksamaan variance dari residual atau tidak dengan melihat hasil hasil uji breusch-pagan-godfrey. (Imam Ghozali, 2013:139)

Tabel 3. Uji Heteroskedastisitas

Heteroskedasticity Test: White

\begin{tabular}{lccc}
\hline F-statistic & 1.322074 & $\begin{array}{l}\text { Prob. F(3,32) } \\
\text { Prob. Chi- }\end{array}$ & 0.2843 \\
$\begin{array}{l}\text { Obs*R-squared } \\
\text { Scaled explained }\end{array}$ & 3.969947 & $\begin{array}{l}\text { Square(3) } \\
\text { Prob. Chi- }\end{array}$ & 0.2647 \\
SS & 3.256179 & \begin{tabular}{l} 
Square(3) \\
\hline
\end{tabular} & 0.3538 \\
\hline
\end{tabular}

hasil dari pengujian heteroskedastisitas memperlihatkan nilai perkalian Obs*R-squared sebesar 3,970. Kemudian dari tabel chi-squareada tingkat kekeliruan $5 \%(0,05)$ dan derajat bebas 3 didapat nilai sebesar 7,815. Apabila dilihat dari nilai Obs*R-squared $(3,970)$ menunjukan nilai kurang dari nilai tabel chi-square $(7,815)$ dan nilai probabilitas chisquareyaitu 0,265 menunjukan nilai lebih besar daripada tingkat kekeliruan 0,05, untuk itu kesimpulannya tidak terdapat gejala heteroskedastisitas pada model ini.

\section{Hasil Uji Autokorelasi}

Dalam penelitian perlu diuji korelasinya antara kesalahan pengganggu t-periode dengan t1nya,

Tabel 4. Uji Autokorelasi

\begin{tabular}{llll}
\hline R-squared & 0.870236 & Mean dependent var & 0.386306 \\
\hline Adjusted R- & & & \\
squared & 0.858070 & S.D. dependent var & 0.817249 \\
S.E. of regression & 0.307887 & Akaike info criterion & 0.586270 \\
Sum squared resid & 3.033416 & Schwarz criterion & 0.762216 \\
Log likelihood & -6.552853 & Hannan-Quinn criter. & 0.647680 \\
F-statistic & 71.53376 & Durbin-Watson stat & 2.126789 \\
Prob(F-statistic) & 0.000000 & & \\
\hline
\end{tabular}


Terhadap Belanja Modal

hasilnya menggunakan uji Durbin-Waton, 2,127. Banyaknya observasi $(n)=36$, banyknya variabel bebas $(k)=3$ dan tingkat kekeliruan/signifikansi $5 \%$, sebagai berikut : $d l=1,295 ., d u=1,654$. Artinya $D W=2,127$ diatas du=1,710 tetapi dibawah nilai 4-du=2,144 yaitu $(1,654<2,127<2,144)$, hasil ini dapat dikatakan bhwa hasilnya tidak ada autokorelasi posistif dan negatif, karena nila DW masih diantara nilai du dan 4-du $(d u<d<4-d u)$.

\section{Hasil Analisis dalam Regresi Linier Berganda}

Berikut hasil analisis regresi linier berganda, yang bertujuan untuk melihat seberapa besar daya hubungan antara beberapa variabel, juga dapat digunakan untuk melihat arah hubungan antara variabel bebas dengan variabel terikat (Imam Ghozali, 2013):

Tabel 5. Regresi Linier Berganda

Dependent Variable: BM

Method: Least Squares

Date: 09/08/17 Time: 11:41

Sample: 136

Included observations: 36

\begin{tabular}{lllll}
\hline Variable & Coefficient & Std. Error & t-Statistic & Prob. \\
PAD & 0.712200 & 0.298991 & 2.382011 & 0.0233 \\
DAU & 3.809328 & 0.745989 & 5.106411 & 0.0000 \\
DAK & 0.195343 & 0.026324 & 7.420676 & 0.0000 \\
C & -0.360721 & 0.088711 & -4.066250 & 0.0003 \\
\hline
\end{tabular}

$$
\begin{gathered}
Y=-0,360721+0,712200 X_{1}+3,809328 X_{2}+ \\
0,195343 X_{3}
\end{gathered}
$$

Berikut penjelasannya: (1) Jika $\alpha=$ konstanta $-0,360721$ artinya jika pendapatan asli daerah (PAD), dana alokasi umum (DAU), dana alokasi khusus (DAK) dianggap konstan (bernilai 0), maka alokasi belanja modal akan bernilai sebesar -0,360721. (2) Jika koefisien regresi variabel pendapatan asli daerah (PAD) memperlihatkan 0,712200, artinya jika pendapatan asli daerah (PAD) meingkat sebanyak 1 satuan, sementara dana alokasi umum (DAU), dana alokasi khusus (DAK) tetap bernilai nol, maka alokasi belanja modal meningkat senilai 0,712200. (3) Jika koefisien regresi dana alokasi umum (DAU) memperlihatkan 3,809328, artinya jika dana alokasi umum (DAU) meningkat sebesar 1 satuan, sementara pendapatan asli daerah (PAD), dana alokasi khusus (DAK) tetap bernilai nol, maka alokasi belanja modal akan meningkat sebesar 3,809328. (4) apabila koefisien dana alokasi khusus (DAK) memperlihatkan sebesar 0,195343, artinya jika dana alokasi khusus (DAK) meningkat sebesar 1 satuan, sementara pendapatan asli daerah (PAD), dana alokasi umum
(DAU) tetap bernilai nol, maka alokasi belanja modal akan meningkat sebesar 0,195343.

\section{PENGUJIAN DALAM HIPOTESIS \\ Tabel 6. Uji Hipotesis}

Dependent Variable: BM

Method: Least Squares

Date: 09/08/17 Time: 11:41

Sample: 136

Included observations: 36

\begin{tabular}{lllll}
\hline Variable & Coefficient & Std. Error & t-Statistic & Prob. \\
PAD & 0.712200 & 0.298991 & 2.382011 & 0.0233 \\
DAU & 3.809328 & 0.745989 & 5.106411 & 0.0000 \\
DAK & 0.195343 & 0.026324 & 7.420676 & 0.0000 \\
C & -0.360721 & 0.088711 & -4.066250 & 0.0003 \\
\hline
\end{tabular}

Uji Hipotesis Parsial (Uji t)

a. Pengujian PAD Terhadap Belanja Modal. Hasilnya didapatkan sebesar 0,023<0,05 dan hasil perbandingannya 2,382 (thitung : $t_{\text {tabel }}$ ), jadi thitung $>t_{\text {tabel }}$ atau 2,382 $>2,037$, kesimpulannya bahwa PAD berpengaruh pada belanja modal.

b. Pengujian DAU pada Belanja Modal. Hasilnya didapatkan sebesar 0,0000<0,05 dan hasil perbandingannya 5,106 , jadi $t_{\text {hitung }}>t_{\text {tabel }}$ atau 5,106>2,037, kesimpulannya bahwa DAU berpengaruh pada belanja modal.

c. Pengujian DAK pada Belanja Modal.

Hasilnya didapatkan sebesar 0,0000<0,05 dan hasil perbandingannya 7.420676 , jadi thitung $>t_{\text {tabel }}$ atau $7.420676>2,037$, kesimpulannya bahwa DAK berpengaruh pada belanja modal.

\section{KESIMPULAN}

Berdasarkan uraian yang telah dibahas pada bab hasil dan pembahasan, seluruh variable yang digunakan berpengaruh pada Belanja modal, sehingga dapat ditarik kesimpulannya yaitu Semakin besar/tinggi Pendapatan Asli Daerah (PAD) maka akan semakin besar juga Alokasi Belanja Modalnya. Begitu juga semakin tinggi Dana Alokasi Umum (DAU) atau Dana Alokasi Khusus (DAK) maka akan semkin besar juga alokasi Belanja Modal.

Akhir kata peneliti mencoba memberikan saran kepaa Pemerintah daerah khususnya Provinsi Jawa Barat agar daat memperhatikan kinerja perangkat daerahnya dalam meningkatkan pendapatan asli daerah, juga dapat meningkatkan efektivitas dalam pemanfaatan dana alokasi umum dan alokasi dana khusus untuk mengatasi ketimpangan fiskal antar daerah.

6. DAFTAR PUSTAKA 
Adisasmita, Rahardjo. 2011. Manajemen Pemerintahan Daerah. Makassar : Graha Ilmu.

Darise, Nurlan. 2007. Pengelolaan Keuangan Daerah. Jakarta : PT.Indeks.

Erlina dan Rasdianto. 2013. Akuntansi Keuangan Daerah Berbasis Akrual. Medan : Brama Ardian.

Ghozali, Imam. 2016. Aplikasi Analisis Multivariate Dengan Program SPSS IBM SPSS 21. Semarang : Badan Penerbit Universitas Diponegoro.

Halim, Abdul. 2007. Akuntansi Sektor Publik Akuntansi Keuangan Daerah, Edisi Revisi, Jakarta : Salemba Empat.

Halim, Abdul dan Syam Kusufi. 2012. Akuntansi Sektor Publik : Teori, Konsep dan Aplikasi. Jakarta : Salemba Empat.

Mardiasmo. 2009. Akuntansi Sektor Publik. Yogyakarta : Penerbit Andi Offset.

Riduwan dan Sunarto. 2012. Pengantar Statistika. Bandung : Alfabeta.

Santoso, Singgih. 2012. Analisis SPSS pada Statistik Parametrik. Jakarta: PT. Elex Media Komputindo.

Sarwono, Jonathan. 2013. Statistika Multivariat ; Aplikasi Untuk Riset Skripsi. Yogyakarta : CV Andi Offset.

Siregar, Doli D. 2004. Manajemen Aset : Strategi Penataan Konsep Pembangunan Berkelanjutan secara Nasional DALAM Konteks Kepala Daerah sebagai Ceo's. Jakarta : Gramedia.

Sugiyono. 2014. Metode Penelitian Kuantitatif, Kualitatif, dan Kombinasi (Mixed Methods). Bandung : Alfabeta

Syaukani, dkk. 2009. Otonomi Daerah Dalam Negara Kesatuan. Yogyakarta : Pustaka Pelajar.

Yani, Ahmad. 2008. Hubungan Keuangan antara Pemerintah Pusat dan Daerah di Indonesia. Jakarta : Raja Grafindo Persada.

Widjaja, Haw. 2009. Otonomi Daerah dan Daerah Otonom. Jakarta : Rajawali Pers.

Winarno, Wing Wahyu, 2015. Analisis Ekonomterika dan Statistik dengan Eviews. Edisi Keempat. Yogyakarta : UPP STIM YPKN

Peraturan Pemerintah Nomor 71 tahun 2010 tentang Standar Akuntansi Pemerintahan.

Permendagri Nomor 59 Tahun 2007 tentang Pedoman Pengelolaan Keuangan Daerah.

Undang-Undang Nomor 1 tahun 2004 Tentang Perbendaharaan Negara.

Undang-Undang Nomor 17 Tahun 2003 Tentang Keuangan Negara.

Undang-Undang Nomor 33 Tahun 2004 tentang Perimbangan Keuangan antara Pemerintah Pusat dan Daerah (sebagai pengganti UndangUndang Nomor 25 Tahun 1999).
Undang-Undang Nomor 23 Tahun 2014 tentang Pemerintahan Daerah (sebagai pengganti Undang-Undang Nomor 32 Tahun 2004). 103

Jannah, Roihatul dkk. 2017. Pengaruh Pendapatan Asli Daerah (Pad), Dana Alokasi Umum (DAU), Dana Alokasi Khusus (DAK), Dan Dana Bagi Hasil (DBH) Terhadap Pengalokasian Belanja Modal.Warta Ekonomi Vol. 07 No 17 Februari 2017. Program Studi Manajemen. Fakultas Ekonomi. Universitas Islam. Malang.

Martini, Ni Luh Dina Selvia dkk. 2014. Pengaruh pendapatan Asli Daerah, Dana Alokasi Umum dan Dana Alokasi Khusus Terhadap Belanja Modal, Pada Kabupaten Buleleng Tahun 20062012. e-Journal Bisma. Volume 2 Tahun 2014. Jurusan Manajemen Universitas Pendidikan Ganesha. Singaraja. Indonesia.

Novianto, R dan Hanafiah, R. (2015). Pengaruh Pendapatan Asli Daerah, Dana Perimbangan dan Kinerja Keuangan terhadap Alokasi Belanja Modal pada Pemerintah Kabupaten/Kota di Provinsi Kalimantan Barat. Jurnal Ekonomi.

Putro, Nugroho Suratno. 2010. Pengaruh Pertumbuhan Ekonomi, Pendapatan Asli Daerah dan Dana Alokasi Umum Terhadap Pengalokasian Anggaran Belanja Modal. Fakultas Ekonomi. Universitas Diponegoro.

Sumarmi, Saptaningsih. 2010. Pengaruh Pendapatan Asli Daerah, Dana Alokasi Umum,dan Dana Alokasi Khusus Terhadap Alokasi Belanja Modal Daerah Kabupaten/Kota di Provinsi D.I. Yogyakarta. Jurnal. Fakultas Ekonomi Universitas PGRI Yogyakarta.

Wandira, Arbie Gugus. 2013. Pengaruh PAD, DAU, DAK, dan DBH Terhadap Pengalokasian Belanja Modal. Accounting Analysis Journal. Jurusan Akuntansi, Fakultas Ekonomi, Universitas Negeri Semarang, Indonesia. ISSN 2252-6765.

Wertianti, I G A Gede dan A.A.N.B. Dwirandra. 2013. Pengaruh Pertumbuhan Ekonomi Pada Belanja Modal Dengan Pad dan DAU Sebagai variabel Moderasi. Fakultas Ekonomi Universitas Udayana (Unud), Bali, Indonesia. E-Jurnal Akuntansi Universitas Udayana 4.3 (2013): 567584. ISSN: 2302-8556.

Faisal, Heri. 2015. APBD 2015, Serapan Belanja Modal Mengkhawatirkan Dikutip dari artikelhttp://finansial.bisnis.com/read/201509 08/10/470103/apbd-2015-serapan-belanjamodal-mengkhawatirkan

Wijanarko, Yusuf. 2013. Realisasi Belanja Modal Prempov Jabar Dinilai Masih Sangat Kecil. Dikutip dari artikel http://www.pikiranrakyat.com/ekonomi/2013/05/14/234780/rea 
lisasi-belanja-modal-pemprov-jabar-dinilaimasih-sangat-kecil. 